\title{
PENERAPAN SISTEM MANAJEMEN KESELAMATAN DAN KESEHATAN KERJA (K3) DAN IDENTIFIKASI POTENSI BAHAYA KERJA (Studi kasus di PT. LTX Kota Cilegon- Banten)
}

\author{
Wahyu Susihono, Feni Akbar Rini \\ Jurusan Teknik Industri - Fakultas Teknik \\ Universitas Sultan Ageng Tirtayasa \\ wahyu.susihono@ft-untirta.ac.id
}

\begin{abstract}
ABSTRAK
Perlindungan terhadap keselamatan dan kesehatan kerja masih jauh dari yang diharapkan karena masih banyak terjadi kecelakaan kerja serta potensi bahaya kerja yang dapat membahayakan tenaga kerja. Penerapkan sistem manajeman keselamatan dan kesehatan kerja (SMK3) perlu dilakukan secara optimal. Penerapan SMK3 di perusahaan belum tentu berbanding lurus terhadap potensi bahaya (hazard) yang ada di lingkungan sekitar perusahaan. Penelitian ini bertujuan untuk mengetahui nilai risiko potensi bahaya kerja dan kategori potensi bahaya kerja di perusahaan serta mengetahui faktor penyebab terbesar terjadinya kecelakaan kerja di perusahaan. Penelitian ini menggunakan pendekatan metode HIRA dan FTA. Hasil yang diperoleh menunjukkan bahwa penerapan SMK3 telah sesuai dengan undang-Undang yang berlaku, namun nilai resiko potensi bahaya bagian fluid utility menunjukkan tingkat keparahan bahaya kerja kecil dan kemungkinan terjadinya potensi bahaya kerja juga kecil, nilai kategori potensi bahaya kerja perlu dikendalikan dengan prosedur rutin. Faktor penyebab potensial terjadinya potensi bahaya adalah suara mesin bising, Standard Operational procedure (SOP) belum terpasang secara ergonomis, terdapat benda asing yang menghalangi jalan, temperatur ruangan meningkat $5^{\circ} \mathrm{C}$ dari temperatur normal.
\end{abstract}

Kata Kunci : Penerapan SMK3, Potensi bahaya, HIRA, FTA

\section{PENDAHULUAN}

\section{A. Latar Belakang}

Pada kenyataannya dalam dunia industri, perlindungan terhadap tenaga kerja masih jauh dari yang diharapkan karena masih banyak terjadi kecelakaan kerja serta potensi bahaya kerja yang dapat membahayakan tenaga kerja. Terkait masalah perlindungan tenaga kerja dari kecelakaan kerja, perusahaan menerapkan sistem manajeman yang dapat melindungi tenaga kerja dari kecelakaan kerja dan menghindari kerugian yang besar terhadap perusahaannya. Salah satu sistem manajeman yang harus diterapkan adalah sistem manajeman keselamatan dan kesehatan kerja (SMK3).

PT.LTX adalah perusahaan yang memproduksi tinplate. Produk yang berkualitas tinggi tersebut tidak terlepas dari kualitas SDM dan faktor lingkungan kerja yang aman serta nyaman untuk para pekerja dalam bekerja, perusahaan memperhatikan tingkat kesejahteraan dan perlindungan kepada tenaga kerja agar produktivitas tenaga kerja meningkat. Fluids utility merupakan unit yang menyadiakan sarana dan prasarana proses, diantaranya: air untuk proses steam, dan udara tekan yang menjadi faktor utama dalam menunjang proses produksi perusahaan. Fluids utility terbagi menjadi 7 unit sistem yang membantu menyediakan sarana dan prasarana proses produksi. Setiap unit sistem tersebut, terdiri dari beberapa mesin yang ditangani oleh beberapa operator. Lingkungan kerja fluids utility yang merupakan penyedia kebutuhan proses produksi dan dilakukan oleh operator pada setiap unitnya. Potensi yang ditimbulkan pada divisi ini seperti suara bising dari mesin, temperatur ruang panas yang diakibatkan dari proses pada mesin-mesin yang dioperasikan, uap zat kimia dan sebagainya. Berkaitan dengan potensi bahaya yang dapat terjadi, alat pelindung diri wajib dipakai oleh operator seperti sepatu safety, masker, sumbat telinga atau ear muff, helmet dan sarung tangan yang 
sesuai dengan fungsinya. Operator terbiasa menggunakan helmet dan sepatu safety saja. Perusahaan telah menyediakan kebutuhan alat pelindung diri untuk semua karyawannya, khususnya di area pabrik, akan tetapi operator atau karyawan yang tidak menggunakan alat pelindung diri secara lengkap disebabkan karena pola kebiasaan dalam melakukan pekerjaan.

Perusahaan telah menerapkan sebuah sistem manajemen keselamatan dan kesehatan kerja. Penerapan sistem manajemen keselamatan dan kesehatan kerja terdiri dari berbagai program untuk melindungi dan mensejahterakan pekerja. Pada kenyataannya dilapangan, penerapan sistem manajemen keselamatan dan kesehatan kerja sulit untuk dilakukan. Berbagai macam program yang telah diterapakan belum menjadi jaminan bagi keselamatan dan kesehatan para pekerja jika tidak diikuti kesadaran dan kepedulian dari pekerja itu sendiri.

\section{B. Perumusan Masalah}

Adapun perumusan masalah dalam penelitian ini adalah sebagai berikut:

1. Berapa nilai risiko potensi bahaya dan kategori potensi bahaya kerja di perusahaan?

2. Apa yang menjadi faktor penyebab terbesar terjadinya kecelakaan kerja di perusahaan?

3. Bagaimana pencapaian SMK3 yang telah diterapkan?

\section{Tujuan Penelitian}

Berdasarkan perumusan masalah yang telah ditentukan, dapat ditentukan tujuan dalam penelitian ini adalah sebagai berikut:

1. Mengetahui nilai risiko potensi bahaya kerja dan kategori potensi bahaya kerja di perusahaan.

2. Mengetahui faktor penyebab terbesar terjadinya kecelakaan kerja di perusahaan.

3. Mengetahui pencapaian SMK3 yang telah diterapkan.

\section{LANDASAN TEORI}

\section{A. Definisi Keselamatan dan Kesehatan}

Keselamatan kerja adalah membuat kondisi kerja yang aman dengan dilengkapi alat-alat pengaman, penerangan yang baik, menjaga lantai dan tangga bebas dari air, minyak, nyamuk dan memelihara fasilitas air yang baik Agus, (1989). Menurut Malthis dkk (2002), Keselamatan kerja menunjuk pada perlindungan kesejahteraan fisik dengan dengan tujuan mencegah terjadinya kecelakaan atau cedera terkait dengan pekerjaan. Pendapat lain menyebutkan bahwa keselamatan kerja berarti proses merencanakan dan mengendalikan situasi yang berpotensi menimbulkan kecelakaan kerja melalui persiapan prosedur operasi standar yang menjadi acuan dalam bekerja (Rika, 2009). Suma'mur (1981), tujuan keselamatan kerja adalah a) Para pegawai mendapat jaminan keselamatan dan kesehatan kerja, b) Agar setiap perlengkapan dan peralatan kerja dapat digunakan sebaik-baiknya.c) Agar semua hasil produksi terpelihara keamanannya d) Agar adanya jaminan atas pemeliharaan dan peningkatan gizi pegawai. e) agar dapat meningkatkan kegairahan, keserasian dan partisipasi kerja f) terhindar dari gangguan kesehatan yang disebabkan oleh lingkungan kerja. g) agar pegawai merasa aman dan terlindungi dalam bekerja.

Husni,L (2005) menyatakan bahwa keselamatan kerja bertalian dengan kecelakaan kerja, yaitu kecelakaan yang terjadi di tempat kerja atau dikenal dengan istilah kecelakaan industri. Kecelakaan industri ini secara umum dapat diartikan sebagai suatu kejadian yang tidak diduga semula dan tidak dikehendaki yang mengacaukan proses yang telah diatur dari suatu aktivitas. Menurut Hadiguna (2009), kecelakaan kerja merupakan kecelakaan seseorang atau kelompok dalam rangka melaksanakan kerja di lingkungan perusahaan, yang terjadi secara tiba-tiba, tidak diduga sebelumnya, tidak diharapkan terjadi, menimbulkan kerugian ringan sampai yang paling berat, dan bisa menghentikan kegiatan pabrik secara total. 
Menurut Undang-undang Pokok Kesehatan RI No. 9 Tahun 1960, Bab I Pasal 2, keadaan sehat diartikan sebagai kesempurnaan yang meliputi keadaan jasmani, rohani dan kemasyarakatan, dan bukan hanya keadaan yang bebas dari penyakit, cacat dan kelemahan-kelemahan lainnya. Menurut Rivai,V (2003) pemantauan kesehatan kerja dapat dilakukan dengan cara a) Mengurangi timbulnya penyakit, b) Penyimpanan catatan tentang lingkungan kerja, c)Memantau kontak langsung, d) Penyaringan genetik.

\section{B. Sistem Manajeman Keselamatan dan Kesehatan Kerja}

Program Keselamatan dan Kesehatan Kerja (K3) adalah suatu sistem yang dirancang untuk menjamin keselamatan yang baik pada semua personel di tempat kerja agar tidak menderita luka maupun menyebabkan penyakit di tempat kerja dengan mematuhi/ taat pada hukum dan aturan keselamatan dan kesehatan kerja, yang tercermin pada perubahan sikap menuju keselamatan di tempat kerja Dewi,R (2006). Menurut Argama,A (2006), program Keselamatan dan Kesehatan Kerja (K3) adalah suatu sistem program yang dibuat bagi pekerja maupun pengusaha sebagai upaya pencegahan (preventif) timbulnya kecelakaan dan penyakit kerja akibat hubungan kerja dalam lingkungan kerja dengan cara mengenali hal-hal yang berpotensi menimbulkan kecelakaan dan penyakit kerja akibat hubungan kerja, dan tindakan antisipatif bila terjadi hal demikian. Dessler (1992) mengatakan bahwa program keselamatan dan kesehatan kerja diselenggarakan karena tiga alasan pokok, a) Moral. b) Hukum. c) Ekonomi.

Modjo,R (2007), manfaat penerapan program keselamatan dan kesehatan kerja di perusahaan antara lain a) Pengurangan Absentisme, b) Pengurangan Biaya Klaim Kesehatan, c) Pengurangan Turnover Pekerja, d) Peningkatan Produktivitas. Hasil penelitian yang dilakukan oleh Wahyu (2006) menunjukkan bahwa secara individual maupun bersama-sama program keselamatan dan kesehatan kerja berpengaruh positif terhadap produktivitas kerja.

\section{Definisi Potensi Bahaya}

Potensi Bahaya (Hazard) adalah suatu kondis/keadaan pada suatu proses, alat, mesin, bahan atau cara kerja yang secara intrisik/alamiah dapat menjadikan luka, cidera bahkan kematian pada manusia serta menimbulkan kerusakan pada alat dan lingkungan. Bahaya (danger) adalah suatu kondisi hazard yang terekspos atau terpapar pada lingkungan sekitar dan terdapat peluang besar terjadinya kecelakan/insiden. Identifikasi bahaya guna mengetahui potensi bahaya dalam setiap pekerjaan dan poses lerja. Identifikasi Bahaya dilakukan bersama pengawas pekerjaan atau petugas K3. Identifikasi Bahaya menggunakan teknik yang sudah dibakukan, misalnya seperti Check List, JSA, JSO,What If, Hazops, dan sebagainya. Semua hasil identifikasi Bahaya harus didokumentasikan dengan baik dan dijadikan sebagai pedoman dalam melakukan setiap kegiatan.

\section{Teknik Identifikasi Potensi Bahaya}

Menurut Safety Enginer Career Workshop (2003), Phytagoras Global Development teknik identifikasi bahaya adalah alat untuk mengidentifikasi berbagai kelemahan potensi resiko yang terdapat dalam proses desain atau operasi suatu sistem atau unit plan yang dapat menimbulkan berbagai konsekuensi yang tidak diinginkan terjadi dan menentukan rekomendasi atau tindakan yang dapat dilakukan untuk eliminasi berbagai resiko atau permasalahan yang mengganggu jalannya proses tersebut atau mengurangi konsekuensi yang dapat ditimbulkan secara sistematis, terstruktur dan baku.

\section{E. Prinsip-prinsip Penerapan Manajeman Keselamatan dan Kesehatan Kerja}

Berikut ini akan dijabarkan prinsip-prinsip dalam melakukan penerapan sistem manajemen keselamatan dan kesehatan kerja adalah a) Komitmen dan Kepemimpinan, 
b) Tinjauan Awal K3, c) Kebijakan K3, c) Perancanaan, d) Penerapan, e) Pengukuran dan Evaluasi, f) Tinjauan ulang dan peningkatan berkesinambungan oleh pihak manajemen.

\section{F. Pengertian Resiko}

Beberapa pengertian resiko yaitu diantaranya, kesempatan sesuatu terjadi yang akan berdampak pada tujuan. Resiko diukur menurut kemungkinan dan konsekuensi. Kemungkinan dan konsekuensi dari terjadinya luka - luka dan penyakit. Kombinasi dari konsekuensi atau kemungkinan kejadian dan konsekuensi dari suatu perisriwa tertentu. Bahaya yang mempunyai potensi dan kemungkinan menimbulkan dampak atau kerugian, kesehatan maupun yang lainnya biasanya dihubungkan dengan resiko (risk). Berdasarkan pemahaman tersebut, resiko dapat diartikan sebagai kemungkinan terjadinya suatu dampak atau konsekuensi.

Pengelolaan resiko (Risk Management) dapat dilakukan dengan menggunakan metode ; a) Identifikasi Resiko (Risk Identification), b) Analisis Resiko (Risk Assessment), c) Pengendalian Resiko. Pada umumnya program K3 yang dilakukan diperusahaan dapat digolongkan atas dua bagian besar yaitu Sistem Manajemen K3 dan Program Teknis Operasional

\section{G. HIRA (Hazzard Identification and Risk Assesment)}

Hira (Hazzard Identification and Risk Assesment) merupakan suatu metode atau teknik untuk mengidentifikasi potensi bahaya kerja dengan mendefinisikan karakteristik bahaya yang mungkin terjadi dan mengevaluasi resiko yang terjadi melalui penilaian resiko dengan menggunakan matriks penilaian resiko. Berikut adalah matriks yang digunakan untuk penilaian resiko dengan menggunakan metode HIRA.

Tabel 1. Tingkat Keparahan

\begin{tabular}{ccl}
\hline Tingkatan & Kriteria & \multicolumn{1}{c}{ Penjelasan } \\
\hline 1 & $\begin{array}{c}\text { Insignificant (tidak } \\
\text { bermakna) } \\
\text { Minor (kecil) }\end{array}$ & $\begin{array}{l}\text { Tidak ada cidera, kerugian materi sangat kecil } \\
\text { Cidera ringan, memerlukan perawatan P3K, langsung } \\
\text { dapat ditangani dilokasi kejadian, kerugian materi sedang }\end{array}$ \\
3 & Moderate (sedang) & $\begin{array}{l}\text { Hilang hari kerja, memerlukan perawatan medis, kerugian } \\
\text { materi cukup besar. } \\
\text { Cidera mengakibatkan cacat atau hilang fungsi tubuh } \\
\text { secara total, kerugian material besar. }\end{array}$ \\
5 & $\begin{array}{c}\text { Major (besar) } \\
\text { Catastrophic } \\
\text { (bencana) }\end{array}$ & Menyebabkan kematian, kerugian materi sangat besar \\
\hline
\end{tabular}

(Sumber: Susihono, 2012)

Tabel 2. Kemungkinan atau Peluang

\begin{tabular}{ccl}
\hline Tingkatan & Kriteria & \multicolumn{1}{c}{ Penjelasan } \\
\hline A & $\begin{array}{c}\text { Almost Certain } \\
\text { (hamper pasti akan } \\
\text { terjadi) }\end{array}$ & $\begin{array}{l}\text { Terjadi hampir pada semua keadaan, misalnya terjadi } 1 \\
\text { kejadian dalam setiap hari. }\end{array}$ \\
B & $\begin{array}{c}\text { Likely (cenderung } \\
\text { untuk terjadi) } \\
\text { Moderate } \\
\text { (mungkin dapat } \\
\text { terjadi) }\end{array}$ & $\begin{array}{l}\text { Sangat mungkin terjadi pada semua keadaan. Misalnya } \\
\text { terjadi } 1 \text { kejadian dalam 1 minggu. } \\
\text { Dapat terjadi sewaktu-waktu. Misalnya, terjadi } 1 \text { kejadian } \\
\text { dalam 1 bulan. }\end{array}$ \\
& $\begin{array}{c}\text { Unlikely (kecil } \\
\text { kemungkinan }\end{array}$ & $\begin{array}{l}\text { Mungkin terjadi sewaktu-waktu. Misalnya, terjadi } 1 \\
\text { kejadian dalam 1 tahun. }\end{array}$ \\
& &
\end{tabular}




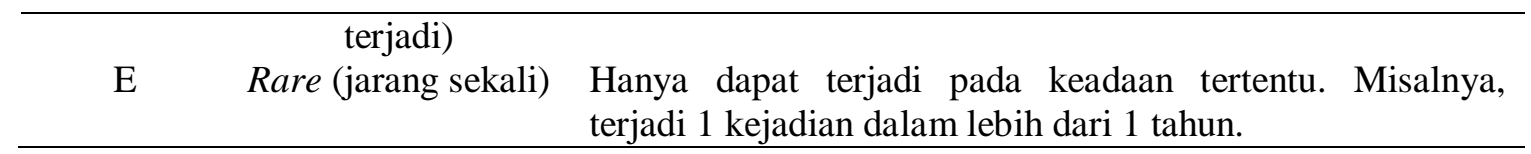

(Sumber: Susihono, 2012)

Penentuan matriks penilaian resiko dengan cara menggabungkan hasil kategori tingkat keparahan dengan kategori kemungkinan atau peluang.

Tabel 3. Matriks Penilaian Resiko

\begin{tabular}{cccccc}
\hline $\begin{array}{c}\text { Kemungkinan } \\
\text { (peluang) }\end{array}$ & $\mathbf{1}$ & $\mathbf{2}$ & $\mathbf{3}$ & $\mathbf{4}$ & $\mathbf{5}$ \\
\cline { 2 - 6 } & $\mathrm{H}$ & $\mathrm{H}$ & $\mathrm{E}$ & $\mathrm{E}$ & $\mathrm{E}$ \\
$\mathrm{A}$ & $\mathrm{M}$ & $\mathrm{H}$ & $\mathrm{H}$ & $\mathrm{E}$ & $\mathrm{E}$ \\
$\mathrm{B}$ & $\mathrm{L}$ & $\mathrm{M}$ & $\mathrm{H}$ & $\mathrm{E}$ & $\mathrm{E}$ \\
$\mathrm{C}$ & $\mathrm{L}$ & $\mathrm{L}$ & $\mathrm{M}$ & $\mathrm{H}$ & $\mathrm{E}$ \\
$\mathrm{D}$ & $\mathrm{L}$ & $\mathrm{L}$ & $\mathrm{M}$ & $\mathrm{H}$ & $\mathrm{H}$ \\
$\mathrm{E}$ & &
\end{tabular}

(Sumber: Susihono, 2012)

Matriks penilaian yang diperoleh terdiri dari 3 kategori L, M, H, dan E. kategori L menunjukkan Low risk, M menunjukkan Moderate risk, $\mathrm{H}$ menunjukkan High risk, dan E menunjukkan Extreme risk. Berikut adalah keterangan lebih lengkap dari matrisk resiko yang diperoleh.

Tabel 4. Keterangan Matriks Resiko

(resiko ekstrim), ememrlukan penangoulangan penghentian kegiatan atau keterlibatan manajemen puncak. Perbaikan sesegara mungkin.

H High Risk (resiko tinggi), memerlukan pihak pelatihan oleh manajemen, penjadwalan tindakan perbaikan secepatnya.

M Moderate Risk (resiko menengah), penangan oleh manajemen terkait.

L Low Rsik (resiko rendah), kendalikan dengan prosedur rutin.

(Sumber: Susihono, 2012)

\section{H. FTA (Fault Tree Anlysis)}

Setiap sistem keselamatan atau mitigasi harus dikuantifikasi kegagalannya. Kegagalan merupakan komplemen dari kesuksesan yaitu $\mathrm{f}=1-\mathrm{s}$. Salah satu cara untuk mengkuantifikasi adalah dengan menggunakan analisis pohon kegagalan. Analisis pohon kegagalan merupakan analisis induktif yaitu suatu kejadian disebabkan oleh kejadian sebelumnya. Kejadian sebelumnya disebabkan oleh kejadian lain lebih lanjut, kegagalan komponen atau kegagalan operator. Masing-masing kegagalan dianalisis lebih lanjut penyebabnya sehingga sampai pada kondisi kejadian dasar (basic event). Analisis pohon kegagalan dapat untuk mengkuantifikasi kegagalan sistem, komponen, fungsi atau operasi. Model pohon kegagalan dapat dipergunakan untuk menentukan a) Kombinasi beberapa kegagalan, b) Probabilitas gagal, c) Titik lemah kritis pada sistem, komponen, fungsi atau operasi. Kejadian puncak (Top Event) dari pohon kegagalan menunjukkan kejadian atau kondisi yang tidak diinginkan (undesired event/undesired state) dari suatu sistem sehingga hasilnya merupakan kegagalan atau ketidaktersediaan (unavailability) sistem. Penyusunan pohon kegagalan merupakan proses berulang dengan mendapatkan umpan balik dari proses PSA lainnya.

Analisis pohon kegagalan merupakan proses yang kompleks sehingga sudah disiapkan perangkat lunak yang digunakan untuk analisis tersebut, misalnya : PSA pack, SAPHIRE, SALP, dan lain-lainnya. Hasil atau keluaran dari perangkat lunak ini pada 
umumnya berupa cut set atau minimal cut set yang dapat menyebabkan terjadinya kejadian puncak. Cut set merupakan kombinasi kegagalan kejadian dasar, sedangkan minimal cut set adalah kombinasi terkecil dari kegagalan kejadian dasar. Analisis pohon kesalahan (fault tree analysis) merupakan salah satu metode yang dapat digunakan untuk menganalisa akar penyebab akar kecelakaan kerja.

\section{Prinsip Penerapan SMK3}

Prinsip penerapan SMK3 sesuai dengan standar OHSAS 18001:2008. Standar OHSAS 18001:2008 didasarakan pada metodologi yang dikenal sebagai Plan-DoCheck-Act (PDCA). Plan berupa penetapan sasaran dan proses yang diperlukan untuk mencapai hasil sesuai dengan kebijakan K3 organisasi. Do melaksanakan proses Check berupa memantau dan mengukur kegiatan proses terhadap kebijakan, sasaran, peraturan perundang-undangan dan persyaratan K3 lainnya serta melaporkan hasilnya. Act yakni mengambil tindakan untuk perbaikan kinerja K3 secara berkelanjutan.

\section{METODOLOGI PENELITIAN}

A. Obyek dan Waktu Penelitian

Tempat penelitian di divisi Produksi bagian Fluid Utility PT LTX Kota Cilegon. Perusahaan ini memproduksi tinplate yang dijual pada pasar Internasional. Area di bagian Fluids Utility terdiri dari area boiler, area kompresor, area Train Demin Water, area Waste Water Treatment Plan (WWTP), area Filter Press, dan area Colling Water. Waktu penelitian dilakukan selama 31 hari pada tahun 2013

\section{B. Pengumpulan Data Penelitian}

a. Data Potensi bahaya di tempat kerja bagian Produksi bagian Fluid Utility, area boiler, area kompresor, area Train Demin Water, area Waste Water Treatment Plan (WWTP), area Filter Press, dan area Colling Water

b. Data penerapan SMK3 di PT LTX

c. Identifikasi Potensi Bahaya

1) HIRA (Hazzard Identification and Risk Assesment)

Mendefinisikan karakteristik bahaya yang mungkin terjadi dan evaluasi resik. Teknik identifikasi bahaya terdiri dari survey keselamatan kerja, patrol keselamatan kerja, mengambil sampel keselamatan kerja, audit keselamatan kerja, pemeriksaan lingkungan, laporan kecelakaan, laporan yang nyaris terjadi dan masukan dari para karyawan.

2) FTA (Fault Tree Analysis)

Membangun model pohon kesalahan (fault tree) dengan cara wawancara dengan manajemen dan melakukan pengamatan langsung terhadap proses produksi di lapangan. Selanjutnya sumber-sumber kecelakaan kerja digambarkan dalam bentuk model pohon kesalahan

\section{HASIL DAN PEMBAHASAN}

Potensi bahaya kerja di PT LTX bagian fluid utility dengan menggunakan metode HIRA teridentifikasi potensi bahaya sebanyak 35 potensi bahaya kerja di bagian fluid utility yang terdiri dari 6 area sebagai area identifikasi. Potensi bahaya kerja yang teridentifikasi dilakukan penilaian lebih lanjut. Proses identifikasi, diperoleh potensi bahaya kerja di area boiler yaitu 10 potensi bahaya kerja. Area kompresor yaitu 5 potensi bahaya kerja. Area train demin water yaitu 3 potensi bahaya kerja. Area WWTP yaitu 6 potensi bahaya kerja. Area filter press yaitu 7 potensi bahaya kerja, dan di area colling water yaitu 4 potensi bahaya kerja.

Penilaian resiko potensi bahaya kerja yang diidentifikasi terdiri dari nilai resiko, kategori resiko, dan program pengendalian resiko yang terjadi. Potensi bahaya yang teridentifikasi di area Boiler yaitu kebisingan $\geq 85 \mathrm{db}$, temperatur ruangan meningkat 33- 
$35^{\circ} \mathrm{C}$, karyawan merasa kegerahan kepanasan suhu tubuh $33-35^{\circ} \mathrm{C}$, letak pressure control terlalu tinggi yaitu 2-5 meter dari lantai, kebocoran gas, ledakan boiler, kebocoran air dalam pipa, display control panel Boiler tidak selurus dengan mata atau dibawah mata \pm 0.5 meter, tersandung, letak control panel barner dan blower tidak selurus dengan mata atau \pm 0.5 meter.

Nilai resiko yang terjadi pada potensi bahaya kerja di area boiler terdiri dari 2C, 1D, 1D, 2D, 2E, 5E, 1D, 2D, 2D, dan 2D. Kategori resiko yang dominan dari nilai resiko pada potensi bahaya kerja di area Boiler adalah L atau low risk yang berarti kendalikan dengan prosedur rutin. Potensi bahaya kerja di area boiler dengan kategori L menunjukkan masih ada kemungkinan potensi yang ada dapat terjadi, untuk dapat lebih memperkecil terjadi potensi bahaya kerja perlu kendalikan prosedur dengan rutin yaitu seperti pengawasan penggunaan APD, pengawasan terhadap lingkungan dan mesin atau perlatan kerja lain yang dapat menimbulkan bahaya kerja.

Potensi bahaya kerja di area Kompresor yang teridentifikasi yaitu kebisingan $\geq 85 \mathrm{db}$, temperatur ruangan meningkat $33-35^{\circ} \mathrm{C}$, letak pressure control tanki angin tidak selurus dengan mata atau diatas mata \pm 1 meter, letak control panel tidak selurus dengan mata atau dibawah mata \pm 0.5 meter, potensi kesulitan pengoperasian panel energi. Nilai resiko dari potensi bahaya kerja di area Kompresor terdiri dari 2C, 1D, 2D, 2D, dan 1C. Kategori resiko yang dominan dari nilai resiko pada potensi bahaya kerja di area Kompresor adalah $\mathrm{L}$ atau low risk yang berarti sama seperti di area Boiler melakukan program pengendalian secara prosedur rutin.

Potensi bahaya kerja di area Train Demin Water teridentifikasi yaitu kebocoran instalasi pipa, letak pressure control dan control panel tidak selurus dengan mata atau diatas mata \pm 0.5 meter, display control box tidak cukup jelas dan tidak ada SOP yang tertulis. Nilai resiko dari potensi bahaya kerja di area Train Demin Water yaitu 2D, 2D, dan 1E, sehingga kategori resiko yang dominan adalah L yang berarti sama dengan area Boiler dan Kompresor dikendalikan dengan prosedur rutin.

Potensi bahaya kerja di area WWTP yaitu terdiri dari menimbulkan uap yang berbau zat kimia, terjatuh dari ketinggian \pm 2 meter dan terpeleset ke dalam kolam \pm 2 meter, tersandung, temperatur ruang meningkat $33-35^{\circ} \mathrm{C}$, kebisingan $\geq 85 \mathrm{db}$, kelelahan kerja. Nilai resiko potensi bahaya kerja di area WWTP yaitu 2C, 2E, 2C, 1D, 2C, dan 1E. Nilai kategori resiko di area WWTP yaitu L dan M. Potensi bahaya kerja di WWTP termasuk dalam kategori low risk dan moderate risk yang berarti selain dikendalikan dengan prosedur rutin, harus ada penangan oleh manajemen terkait untuk lebih memeperkecil potensi bahaya yang akan terjadi.

Potensi bahaya kerja yang teridentifikasi di area Filter Press yaitu temperatur ruang meningkat $33-35^{\circ} \mathrm{C}$, tersandung, kurang pencahayaan $\leq 100$ lux, karyawan merasa kegerahan atau kepanasan suhu tubuh $33-35^{\circ} \mathrm{C}$, letak control panel tidak selurus dengan mata atau dibawah mata $\pm 25 \mathrm{~cm}$, letak pressure control tanki angin terlalu tinggi \pm 0.5 meter, kesulitan dalam membuka keran tanki angin. Nilai resiko di area Filter Press yaitu 1D, 2C, 2D, 1C, 2D, 2D, dan 1E. Nilai kategori resiko yang dominan pada potensi bahaya kerja di area Filter Press yaitu L yang berarti sama seperti pada potensi bahaya kerja di area Boiler.

Pada penelitian yang dilakukan oleh Fristiyan, A (2010) yang tentang identifikasi bahaya dan upaya pengendalian yang dilakukan pada pekerja Railing di PT PP (Persero) Proyek Fakultas Kedokteran dan Ilmu Kesehatan Universitas Islam Negeri Jakarta, identifikasi bahaya dilakukan dengan metode JSA. Penilaian bahaya yang telah diidentifikasi terdiri dari nilai S yaitu Severity atau keparahan, P yaitu probability atau kemungkinan terjadi, C yaitu Control atau pengendalian resiko, A yaitu Awareness atau kesadaran akan resiko. Penilaian bahaya diisi dengan skala 1-5 dan kemudian di total serta dikategorikan ke dalam level. Penilaian bahaya telah dilakukan, selanjutnya membuat rekomendasi yaitu elimanasi, subtitusi, engineering control, tanda peringatan, APD, tidak bermasalah, sedangkan pada penelitian Fristiyan (2010) dapat dihasilkan bahwa bahaya yang 
diidentifikasi yaitu tersengat listrik dengan level high direkomendasikan tanda peringatan dan APD, sesak nafas dengan level low direkomendasikan tanda peringatan dan APD, kebakaran dengan level high direkomendasikan tanda peringatan dan APD, jatuh dari ketinggian dengan level high direkomendasikan engineering control, tanda peringatan dan APD, dan kejatuhan material dengan level low.

1. Penilaian Resiko Bahaya Kerja dengan HIRA

Penilaian resiko potensi bahaya kerja di bagian Fluid Utility adalah sebagai berikut.

Tabel 5. Penilaian Resiko Potensi Bahaya Kerja

\begin{tabular}{|c|c|c|c|c|c|}
\hline \multirow[b]{2}{*}{ Kegiatan } & \multicolumn{2}{|c|}{ Identifikasi Sumber Bahaya } & \multicolumn{3}{|c|}{ Penilaian Resiko } \\
\hline & $\begin{array}{l}\text { Potensi } \\
\text { Bahaya }\end{array}$ & Dampak & $\begin{array}{l}\text { Nilai } \\
\text { Resiko }\end{array}$ & $\begin{array}{c}\text { Kategori } \\
\text { Resiko }\end{array}$ & $\begin{array}{c}\text { Program } \\
\text { Pengendalian } \\
\text { Resiko }\end{array}$ \\
\hline $\begin{array}{l}\text { Pengoperasian } \\
\text { dan } \\
\text { pengecekan } \\
\text { Boiler }\end{array}$ & $\begin{array}{l}\text { Kebisingan } \geq \\
85 \mathrm{db}\end{array}$ & $\begin{array}{l}\text { Pendengaran } \\
\text { terganggu }\end{array}$ & $2 \mathrm{C}$ & M & $\begin{array}{l}\text { Menggunakan } \\
\text { earmuff }\end{array}$ \\
\hline $\begin{array}{l}\text { Pengoperasian } \\
\text { dan } \\
\text { pengecekan } \\
\text { Boiler }\end{array}$ & $\begin{array}{l}\text { Temperatur } \\
\text { ruangan } \\
\text { meningkat 33- } \\
35^{\circ} \mathrm{C}\end{array}$ & $\begin{array}{l}\text { Suhu tubuh } \\
\text { meningkat }\end{array}$ & & & $\begin{array}{l}\text { Membuka pintu } \\
\text { ruangan }\end{array}$ \\
\hline $\begin{array}{l}\text { Pengoperasian } \\
\text { dan } \\
\text { pengecekan } \\
\text { Boiler }\end{array}$ & $\begin{array}{l}\text { Karyawan } \\
\text { merasa } \\
\text { kegerahan atau } \\
\text { kepanasan, } \\
\text { suhu tubuh 33- } \\
35^{\circ} \mathrm{C}\end{array}$ & $\begin{array}{l}\text { Konsentrasi } \\
\text { terganggu dan } \\
\text { konsumsi } \\
\text { energi } \\
\text { meningkat }\end{array}$ & 1D & $\mathrm{L}$ & $\begin{array}{l}\text { Menggunakan } \\
\text { pakaian anti panas }\end{array}$ \\
\hline $\begin{array}{l}\text { Pengoperasian } \\
\text { dan } \\
\text { Pengecekan } \\
\text { Boiler }\end{array}$ & $\begin{array}{l}\text { Letak pressure } \\
\text { control terlalu } \\
\text { tinggi yaitu 2- } \\
3 \text { meter dari } \\
\text { lantai }\end{array}$ & $\begin{array}{l}\text { Kelelahan } \\
\text { pada mata dan } \\
\text { leher }\end{array}$ & 2D & $\mathrm{L}$ & $\begin{array}{l}\text { Menggunakan alat } \\
\text { bantu }\end{array}$ \\
\hline $\begin{array}{l}\text { Proses steam } \\
\text { uap untuk } \\
\text { pemanasan } \\
\text { dalam proses } \\
\text { produksi }\end{array}$ & Kebocoran gas & $\begin{array}{l}\text { Terganggu } \\
\text { pernapasan }\end{array}$ & $2 \mathrm{E}$ & $\mathrm{L}$ & $\begin{array}{l}\text { Maintenance pipa } \\
\text { saluran gas secara } \\
\text { berkala dan } \\
\text { menggunakan } \\
\text { masker }\end{array}$ \\
\hline $\begin{array}{l}\text { Proses steam } \\
\text { uap untuk } \\
\text { pemanasan } \\
\text { dalam proses } \\
\text { produksi }\end{array}$ & $\begin{array}{l}\text { Ledakan } \\
\text { Boiler }\end{array}$ & $\begin{array}{l}\text { Kehancuran } \\
\text { pabrik }\end{array}$ & $5 \mathrm{E}$ & $\mathrm{H}$ & $\begin{array}{l}\text { Maintenance dan } \\
\text { controlling kondisi } \\
\text { boiler secara } \\
\text { berkala dan } \\
\text { jauhkan dari } \\
\text { sumber api } \\
\text { langsung (seperti } \\
\text { rokok, dll) }\end{array}$ \\
\hline $\begin{array}{l}\text { Proses steam } \\
\text { uap untuk } \\
\text { pemanasan } \\
\text { dalam proses } \\
\text { produksi }\end{array}$ & $\begin{array}{l}\text { Kebocoran air } \\
\text { dalam pipa }\end{array}$ & $\begin{array}{l}\text { Area licin dan } \\
\text { terpeleset }\end{array}$ & 1D & $\mathrm{L}$ & $\begin{array}{l}\text { Maintenance pipa } \\
\text { saluran air secara } \\
\text { berkala dan } \\
\text { menggunakan } \\
\text { masker }\end{array}$ \\
\hline
\end{tabular}




\begin{tabular}{|c|c|c|c|c|c|}
\hline $\begin{array}{l}\text { Pengoperasian } \\
\text { dan } \\
\text { pengecekan } \\
\text { Boiler }\end{array}$ & $\begin{array}{l}\text { Display } \\
\text { control Panel } \\
\text { Boiler tidak } \\
\text { selurus dengan } \\
\text { mata, dibawah } \\
\text { mata } \pm 0.5 \\
\text { meter } \\
\end{array}$ & $\begin{array}{l}\text { Kelelahan } \\
\text { terhadap mata } \\
\text { dan leher }\end{array}$ & \multirow{3}{*}{$2 \mathrm{D}$} & \multirow{3}{*}{$\mathrm{L}$} & $\begin{array}{l}\text { Menggunakan alat } \\
\text { bantu }\end{array}$ \\
\hline $\begin{array}{l}\text { Pengoperasian } \\
\text { dan } \\
\text { pengecekan } \\
\text { Boiler }\end{array}$ & Tersandung & Terluka & & & $\begin{array}{l}\text { Merapihkan kabel } \\
\text { dan memberi } \\
\text { rambu peringatan }\end{array}$ \\
\hline $\begin{array}{l}\text { Pengoperasian } \\
\text { dan } \\
\text { pengecekan } \\
\text { Boiler }\end{array}$ & $\begin{array}{l}\text { Letak control } \\
\text { panel barner } \\
\text { dan blower } \\
\text { tidak selurus } \\
\text { dengan mata, } \\
\text { dibawah mata } \\
\pm 0.5 \text { meter }\end{array}$ & $\begin{array}{l}\text { Kelelahan } \\
\text { pada mata, } \\
\text { leher dan } \\
\text { cidera tulang } \\
\text { belakang }\end{array}$ & & & $\begin{array}{l}\text { Menggunakan alat } \\
\text { bantu }\end{array}$ \\
\hline $\begin{array}{l}\text { Pengoperasian } \\
\text { dan } \\
\text { pengecekan } \\
\text { Kompresor }\end{array}$ & $\begin{array}{l}\text { Kebisingan } \geq \\
\text { 85db }\end{array}$ & $\begin{array}{l}\text { Pendengaran } \\
\text { terganggu }\end{array}$ & $2 \mathrm{C}$ & M & $\begin{array}{l}\text { Menggunakan } \\
\text { earmuff }\end{array}$ \\
\hline $\begin{array}{l}\text { Pengoperasian } \\
\text { dan } \\
\text { pengecekan } \\
\text { Kompresor }\end{array}$ & $\begin{array}{l}\text { Temperatur } \\
\text { ruangan } \\
\text { meningkat 33- } \\
35^{\circ} \mathrm{C}\end{array}$ & $\begin{array}{l}\text { Suhu tubuh } \\
\text { meningkat }\end{array}$ & $1 \mathrm{D}$ & $\mathrm{L}$ & $\begin{array}{l}\text { Membuka pintu } \\
\text { ruangan dan } \\
\text { membuat saluran } \\
\text { untuk angin panas } \\
\text { keluaran dari } \\
\text { kompresor } \\
\end{array}$ \\
\hline $\begin{array}{l}\text { Pengoperasian } \\
\text { dan } \\
\text { pengecekan } \\
\text { kompresor }\end{array}$ & $\begin{array}{l}\text { Letak } \\
\text { Pressure } \\
\text { control tanki } \\
\text { angin tidak } \\
\text { selurus dengan } \\
\text { mata, diatas } \\
\text { mata } \pm 1 \text { meter. }\end{array}$ & $\begin{array}{l}\text { Kelelahan } \\
\text { pada mata dan } \\
\text { leher }\end{array}$ & $2 \mathrm{D}$ & $\mathrm{L}$ & $\begin{array}{l}\text { Menggunakan alat } \\
\text { bantu }\end{array}$ \\
\hline $\begin{array}{l}\text { Pengoperasian } \\
\text { dan } \\
\text { pengecekan } \\
\text { kompresor }\end{array}$ & $\begin{array}{l}\text { Letak control } \\
\text { panel tidak } \\
\text { selurus dengan } \\
\text { mata, dibawah } \\
\text { mata } \pm 0.5 \\
\text { meter } \\
\end{array}$ & $\begin{array}{l}\text { Kelelahan } \\
\text { pada mata dan } \\
\text { leher serta } \\
\text { cidera tulang } \\
\text { belakang }\end{array}$ & & & $\begin{array}{l}\text { Menggunakan alat } \\
\text { bantu }\end{array}$ \\
\hline $\begin{array}{l}\text { Pengoperasian } \\
\text { dan } \\
\text { pengecekan } \\
\text { kompresor }\end{array}$ & $\begin{array}{l}\text { Potensi } \\
\text { kesulitan } \\
\text { pengoperasian } \\
\text { panel energy }\end{array}$ & $\begin{array}{l}\text { Konsentrasi } \\
\text { menurun dan } \\
\text { konsumsi } \\
\text { energi } \\
\text { meningkat }\end{array}$ & $1 \mathrm{C}$ & $\mathrm{L}$ & $\begin{array}{l}\text { Menggunakan alat } \\
\text { bantu }\end{array}$ \\
\hline $\begin{array}{l}\text { Proses } \\
\text { regenerasi }\end{array}$ & $\begin{array}{l}\text { Kebocoran } \\
\text { instalasi pipa }\end{array}$ & $\begin{array}{l}\text { Pernapasan } \\
\text { terganggu dan } \\
\text { menimbulkan } \\
\text { penyakit kulit }\end{array}$ & $2 \mathrm{D}$ & $\mathrm{L}$ & $\begin{array}{l}\text { Maintenance pipa } \\
\text { saluran air secara } \\
\text { berkala dan } \\
\text { menggunakan } \\
\text { masker }\end{array}$ \\
\hline Proses & Letak pressure & Kelelahan & & & Menggunakan alat \\
\hline
\end{tabular}




\begin{tabular}{|c|c|c|c|c|c|}
\hline regenerasi & $\begin{array}{l}\text { control dan } \\
\text { control panel } \\
\text { tidak selurus } \\
\text { dengan mata, } \\
\text { diatas mata } \\
\pm 0.5 \text { meter } \\
\end{array}$ & $\begin{array}{l}\text { pada mata dan } \\
\text { leher }\end{array}$ & & & bantu \\
\hline $\begin{array}{l}\text { Proses } \\
\text { regenerasi }\end{array}$ & $\begin{array}{l}\text { Display } \\
\text { control box } \\
\text { tidak cukup } \\
\text { jelas dan tidak } \\
\text { ada SOP yang } \\
\text { tertulis }\end{array}$ & $\begin{array}{l}\text { Kesalahan } \\
\text { pengoperasian }\end{array}$ & $1 \mathrm{E}$ & $\mathrm{L}$ & $\begin{array}{l}\text { Membuat SOP } \\
\text { tertulis dan } \\
\text { mengganti control } \\
\text { box yang cukup } \\
\text { jelas }\end{array}$ \\
\hline $\begin{array}{l}\text { Pengolahan air } \\
\text { limbah }\end{array}$ & $\begin{array}{l}\text { Menimbulkan } \\
\text { uap yang } \\
\text { berbau zat } \\
\text { kimia }\end{array}$ & $\begin{array}{l}\text { Pernapasan } \\
\text { terganggu dan } \\
\text { pusing }\end{array}$ & $2 \mathrm{C}$ & M & $\begin{array}{l}\text { Menggunakan } \\
\text { masker kimia }\end{array}$ \\
\hline $\begin{array}{l}\text { Pengolahan air } \\
\text { limbah }\end{array}$ & $\begin{array}{l}\text { Terjatuh dari } \\
\text { ketinggian } \pm 2 \\
\text { meter dan } \\
\text { terpeleset ke } \\
\text { dalam kolam } \\
\pm 2 \text { meter }\end{array}$ & $\begin{array}{l}\text { Terluka dan } \\
\text { membuat kulit } \\
\text { gatal }\end{array}$ & $2 \mathrm{E}$ & $\mathrm{L}$ & $\begin{array}{l}\text { Menggunakan } \\
\text { safety belt dan } \\
\text { memberi pembatas }\end{array}$ \\
\hline $\begin{array}{l}\text { Pengolahan air } \\
\text { limbah }\end{array}$ & Tersandung & Terluka & $2 \mathrm{C}$ & M & $\begin{array}{l}\text { Memasang rambu } \\
\text { peringatan dan } \\
\text { membebaskan area } \\
\text { jalan dari selang } \\
\text { atau benda yang } \\
\text { menghalangi }\end{array}$ \\
\hline $\begin{array}{l}\text { Pengolahan air } \\
\text { limbah }\end{array}$ & $\begin{array}{l}\text { Kebisingan } \geq \\
\text { 85db }\end{array}$ & $\begin{array}{l}\text { Pendengaran } \\
\text { terganggu }\end{array}$ & & & $\begin{array}{l}\text { Menggunakan } \\
\text { earmuff }\end{array}$ \\
\hline $\begin{array}{l}\text { Pengolahan air } \\
\text { limbah }\end{array}$ & $\begin{array}{l}\text { Temperatur } \\
\text { ruang } \\
\text { meningkat 33- } \\
35^{\circ} \mathrm{C} \text {. }\end{array}$ & $\begin{array}{l}\text { Suhu tubuh } \\
\text { meningkat }\end{array}$ & & & $\begin{array}{l}\text { Menggunakan } \\
\text { pakaian yang } \\
\text { terbuat dari bahan } \\
\text { yang nyaman }\end{array}$ \\
\hline $\begin{array}{l}\text { Pengecekan } \\
\text { dan } \\
\text { pengoperasian } \\
\text { filter press }\end{array}$ & $\begin{array}{l}\text { Temperatur } \\
\text { ruang } \\
\text { meningkat 33- } \\
35^{0} \mathrm{C}\end{array}$ & $\begin{array}{l}\text { Suhu tubuh } \\
\text { meningkat }\end{array}$ & $1 \mathrm{D}$ & $\mathrm{L}$ & $\begin{array}{l}\text { Membuat ventilasi } \\
\text { udara yang baik } \\
\text { dan memberi jarak } \\
\text { anatara mesin } \\
\text { dengan atap yang } \\
\text { lebih longgar }\end{array}$ \\
\hline $\begin{array}{l}\text { Pengolahan air } \\
\text { limbah }\end{array}$ & $\begin{array}{l}\text { Kelelahan } \\
\text { kerja }\end{array}$ & $\begin{array}{l}\text { Konsumsi } \\
\text { energi } \\
\text { meningkat } \\
\text { dan } \\
\text { konsentrasi } \\
\text { menurun }\end{array}$ & $1 \mathrm{E}$ & $\mathrm{L}$ & $\begin{array}{l}\text { Tidak terlalu lama } \\
\text { dalam melakukan } \\
\text { pengecekan dengan } \\
\text { posisi berdiri }\end{array}$ \\
\hline $\begin{array}{l}\text { Pengecekan } \\
\text { dan } \\
\text { pengoperasian } \\
\text { filter press }\end{array}$ & Tersandung & Terluka & $2 \mathrm{C}$ & $\mathrm{M}$ & $\begin{array}{l}\text { Memberi rambu- } \\
\text { rambu peringatan }\end{array}$ \\
\hline $\begin{array}{l}\text { Pengecekan } \\
\text { dan }\end{array}$ & $\begin{array}{l}\text { Kurang } \\
\text { pencahayaan, }\end{array}$ & $\begin{array}{l}\text { Terjepit dan } \\
\text { penglihatan }\end{array}$ & $2 \mathrm{D}$ & $\mathrm{L}$ & Menyalakan lampu \\
\hline
\end{tabular}




\begin{tabular}{|c|c|c|c|c|c|}
\hline $\begin{array}{l}\text { pengoperasian } \\
\text { filter press }\end{array}$ & $\begin{array}{l}\text { cahaya } \leq 100 \\
\text { lux }\end{array}$ & kurang jelas & & & \\
\hline $\begin{array}{l}\text { Pengecekan } \\
\text { dan } \\
\text { pengoperasian } \\
\text { filter press }\end{array}$ & $\begin{array}{l}\text { Karyawan } \\
\text { merasa } \\
\text { kegerahan atau } \\
\text { kepanasan, } \\
\text { suhu tubuh 33- } \\
35^{\circ} \mathrm{C}\end{array}$ & $\begin{array}{l}\text { Konsumsi } \\
\text { energi } \\
\text { meningkat } \\
\text { dan } \\
\text { konsentrasi } \\
\text { menurun }\end{array}$ & $1 \mathrm{C}$ & $\mathrm{L}$ & $\begin{array}{l}\text { Menggunakan } \\
\text { pakaian anti panas }\end{array}$ \\
\hline $\begin{array}{l}\text { Pengecekan } \\
\text { dan } \\
\text { pengoperasian } \\
\text { filter press }\end{array}$ & $\begin{array}{l}\text { Letak control } \\
\text { panel tidak } \\
\text { selurus dengan } \\
\text { mata, dibawah } \\
\text { mata } \pm 25 \mathrm{~cm}\end{array}$ & $\begin{array}{l}\text { Kelelahan } \\
\text { pada mata dan } \\
\text { leher }\end{array}$ & \multirow{2}{*}{$2 \mathrm{D}$} & \multirow[b]{2}{*}{$\mathrm{L}$} & $\begin{array}{l}\text { Menggunakan alat } \\
\text { bantu }\end{array}$ \\
\hline $\begin{array}{l}\text { Pengecekan } \\
\text { dan } \\
\text { pengoperasian } \\
\text { filter press }\end{array}$ & $\begin{array}{l}\text { Letak pressure } \\
\text { control tanki } \\
\text { angin terlalu } \\
\text { tinggi } \pm 0.5 \\
\text { meter }\end{array}$ & $\begin{array}{l}\text { Kelelahan } \\
\text { pada mata dan } \\
\text { leher }\end{array}$ & & & $\begin{array}{l}\text { Menggunakan alat } \\
\text { bantu }\end{array}$ \\
\hline $\begin{array}{l}\text { Pengecekan } \\
\text { dan } \\
\text { pengoperasian } \\
\text { filter press }\end{array}$ & $\begin{array}{l}\text { Kesulitan } \\
\text { dalam } \\
\text { membuka kran } \\
\text { tanki angin } \\
\end{array}$ & $\begin{array}{l}\text { Kesalahan } \\
\text { pengoperasian }\end{array}$ & $1 \mathrm{E}$ & $\mathrm{L}$ & $\begin{array}{l}\text { Menggunakan alat } \\
\text { bantu }\end{array}$ \\
\hline $\begin{array}{l}\text { Proses } \\
\text { Pendinginan } \\
\text { air }\end{array}$ & $\begin{array}{l}\text { Kebisingan } \geq \\
\text { 85db }\end{array}$ & $\begin{array}{l}\text { Pendengaran } \\
\text { terganggu }\end{array}$ & $2 \mathrm{C}$ & M & $\begin{array}{l}\text { Menggunakan } \\
\text { earmuff }\end{array}$ \\
\hline $\begin{array}{l}\text { Proses } \\
\text { Pendinginan } \\
\text { air }\end{array}$ & $\begin{array}{l}\text { Temperatur } \\
\text { ruang } \\
\text { meningkat 33- } \\
35^{\circ} \mathrm{C}\end{array}$ & $\begin{array}{l}\text { Suhu tubuh } \\
\text { meningkat }\end{array}$ & $1 \mathrm{D}$ & $\mathrm{L}$ & $\begin{array}{l}\text { Membuka pintu } \\
\text { ruang colling water }\end{array}$ \\
\hline $\begin{array}{l}\text { Proses } \\
\text { Pendinginan } \\
\text { air }\end{array}$ & $\begin{array}{l}\text { Peringatan } \\
\text { SOP yang } \\
\text { kurang jelas }\end{array}$ & $\begin{array}{l}\text { Kesalahan } \\
\text { pengoperasian }\end{array}$ & $1 \mathrm{E}$ & $\mathrm{L}$ & $\begin{array}{l}\text { Merubah } \\
\text { peringatan SOP } \\
\text { dengan display } \\
\text { yang lebih terlihat } \\
\text { dengan jelas } \\
\end{array}$ \\
\hline
\end{tabular}

\section{Hasil analisis Fault Tree Analysis (FTA)}

Penentuan kejadian puncak yang teridentifikasi ada 6 kejadian puncak. Pertama, yaitu kebisingan $\geq 80 \mathrm{db}$. Kedua, yaitu temperatur ruangan meningkat $33-35^{\circ} \mathrm{C}$. Ketiga, yaitu kebocoran gas, kebocoran air, kebocoran instalsi pipa dan ledakan boiler. Kempat, yaitu timbul uap dan bau dari zat kimia. Kelima, yaitu terjatuh, terpeleset dan tersandung. Keenam, yaitu kesulitan pengoperasian dan kelelahan kerja. Penyebab dasar potensi bahaya kebisingan $\geq 85 \mathrm{db}$ diantaranya disebabkan 6 penyebab dasar. Potensi bahaya temperatur ruangan meningkat $33-35^{\circ} \mathrm{C}$ disebabkan oleh 6 penyebab dasar. Potensi bahaya kebocoran gas, kebocoran air, kebocoran instalasi pipa dan ledakan boiler disebabkan oleh 8 penyebab dasar. Potensi bahaya timbul uap dan bau dari zat kimia disebabkan oleh 16 penyebab dasar. 16 penyebab dasar diantaranya yaitu, proses pencucian strip dengan larutan elektrolit, pembilasan permukaan strip, proses pickling dengan larutan elektrolit, proses chemical treatment dengan larutan elektrolit, limbah acid, limbah alkaline, limbah cooling water, limbah demineralization, limbah chrom, limbah padat, DOS, PSA, $\mathrm{Na}_{2} \mathrm{Cr}_{0} 7, \mathrm{NaOH}$, Stanous sulfat, dan ENSA. Potensi bahaya terjatuh, terpeleset, dan tersandung disebabkan oleh 5 penyebab dasar. Pada penelitian 
Sutanto,H (2010) dengan judul analisis faktor-faktor penyebab kecelakaan kerja pada pembangunan gedung perkantoran dan perkuliahan tahap II Universitas Wijaya Kusuma Surabaya, faktor-faktor penyebab dengan menggunakan FTA. Tahap penentuan penyebab terjadinya kecelakaan dilakukan dengan menentukan top event dan diuraikan ke intermediet event. Berikut adalah beberapa hasil analisis FTA beberpaa penyebab potensi bahaya.

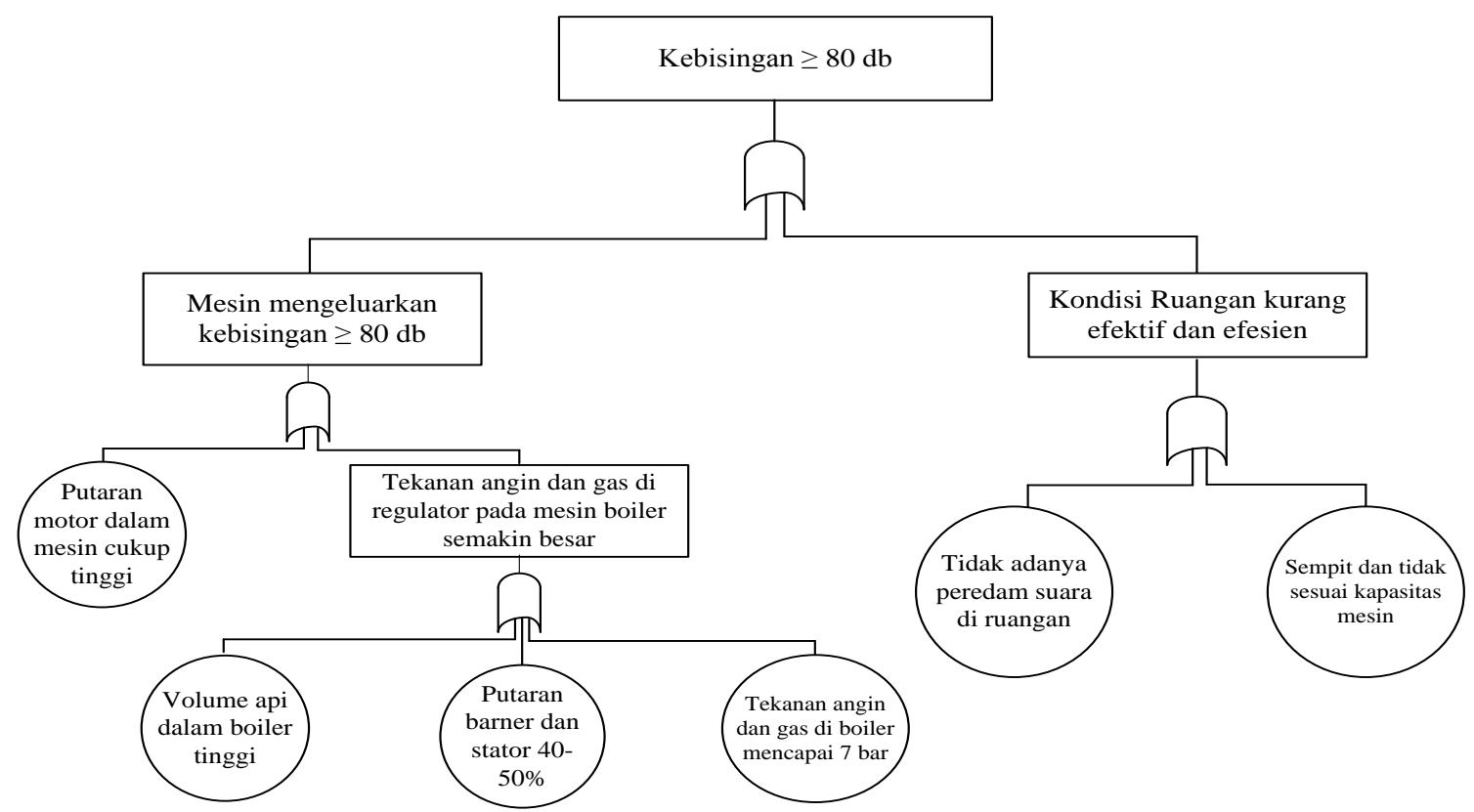

Gambar 1. Penyebab Potensi Bahaya Kebisingan

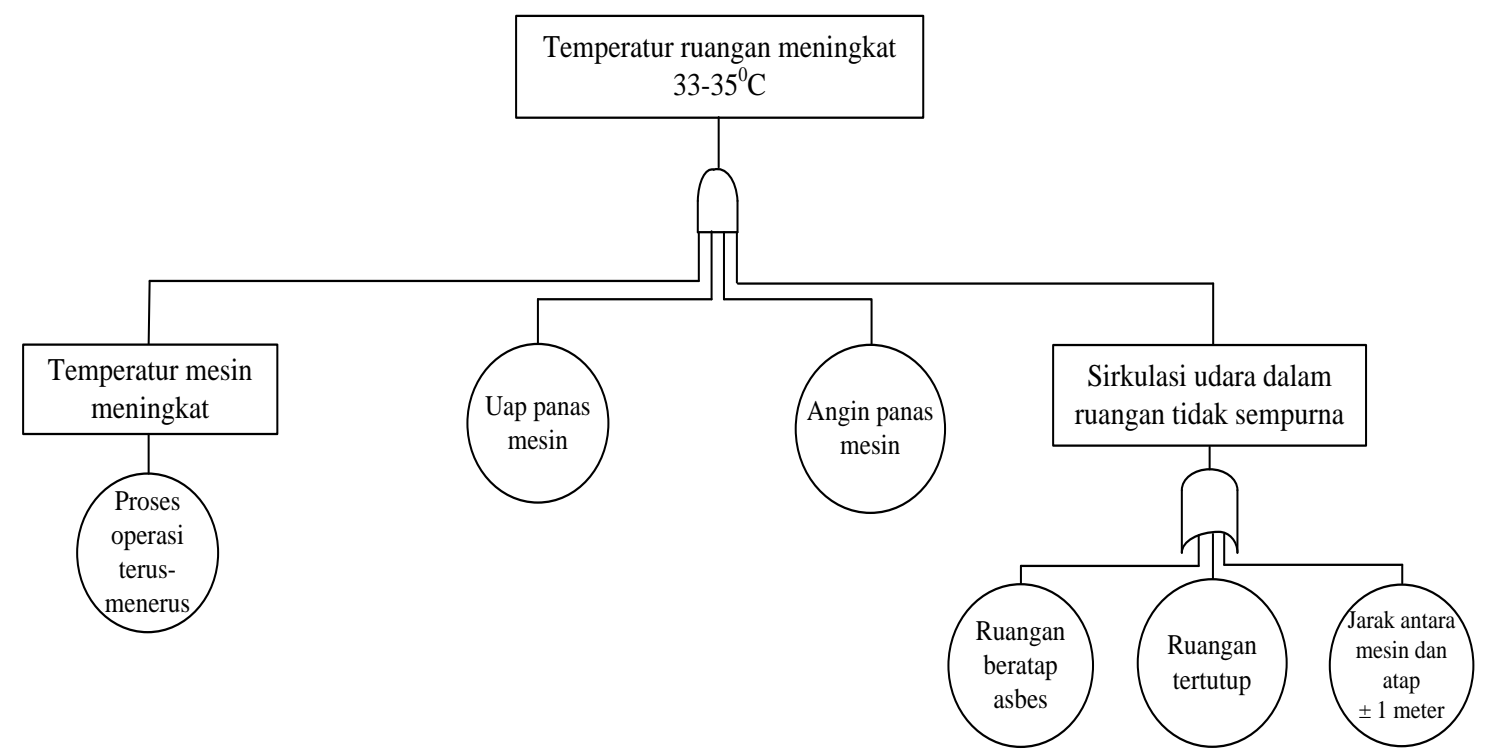

Gambar 2. Penyebab Potensi Bahaya Temperatur Ruangan Meningkat 


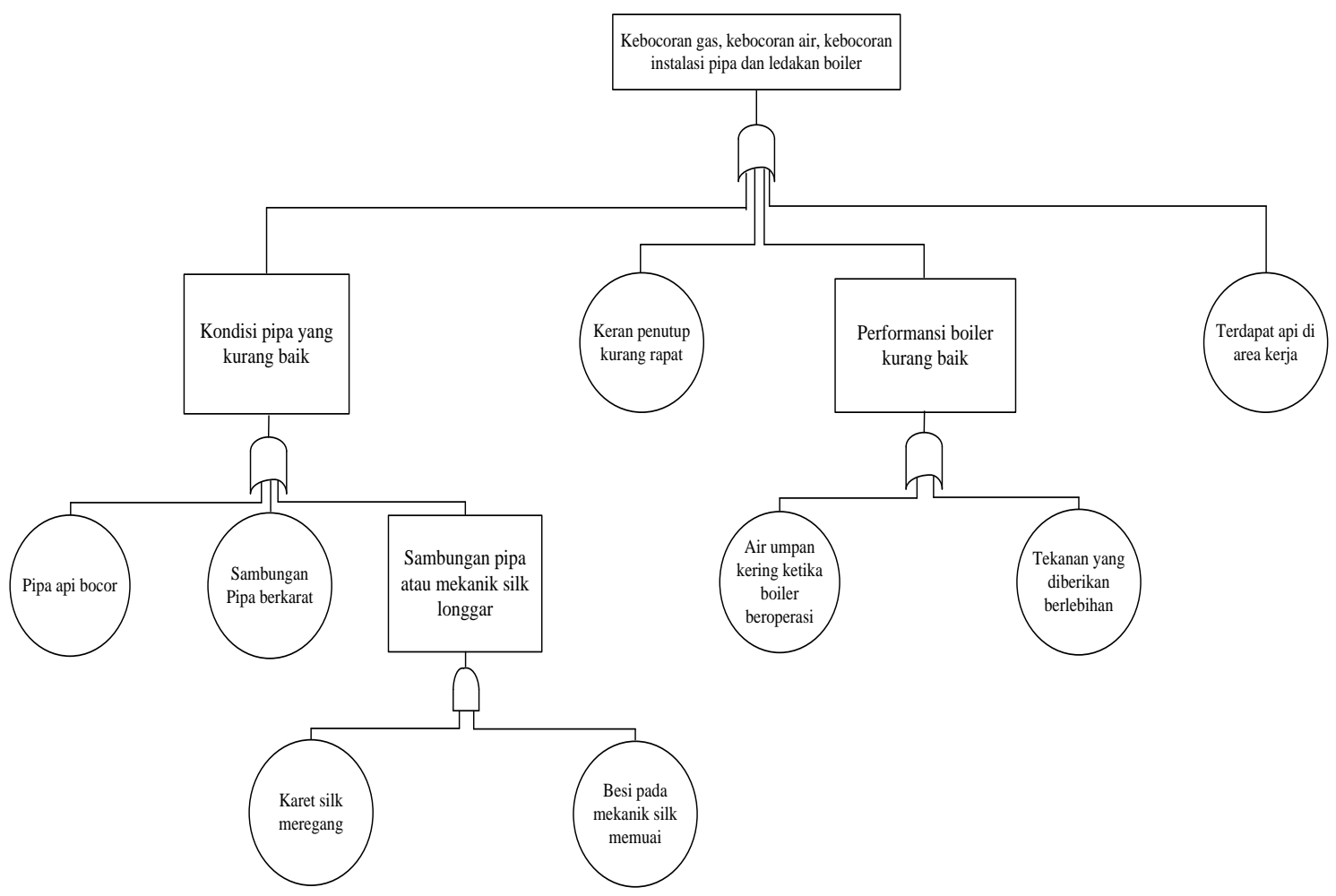

Gambar 3. Penyebab Potensi Bahaya Kebocoran gas, Kebocoran Air, Kebocoran Instalasi Pipa, dan Ledakan Boiler

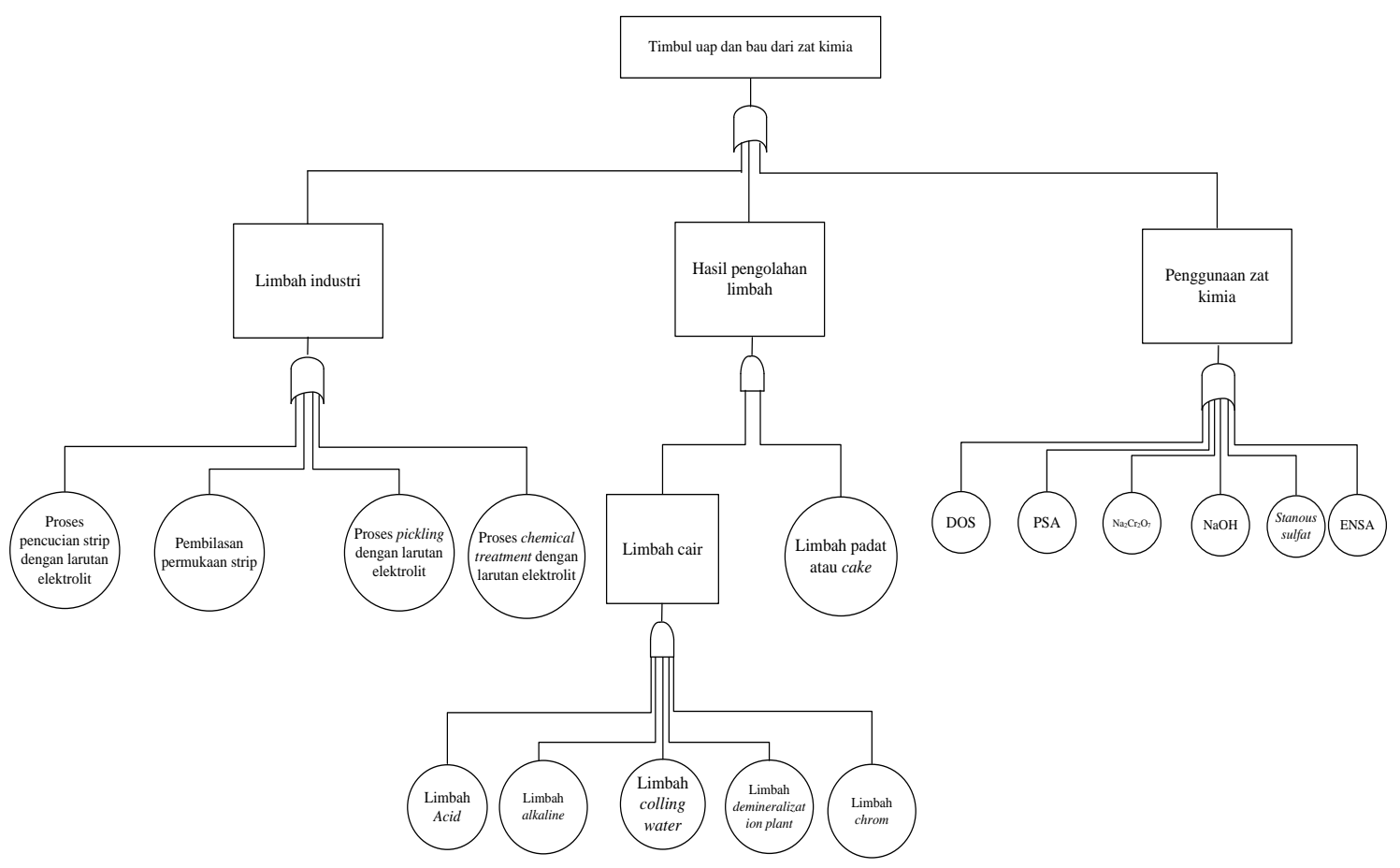

Gambar 4. Penyebab Potensi Bahaya Timbul Uap dan Bau Zat Kimia 


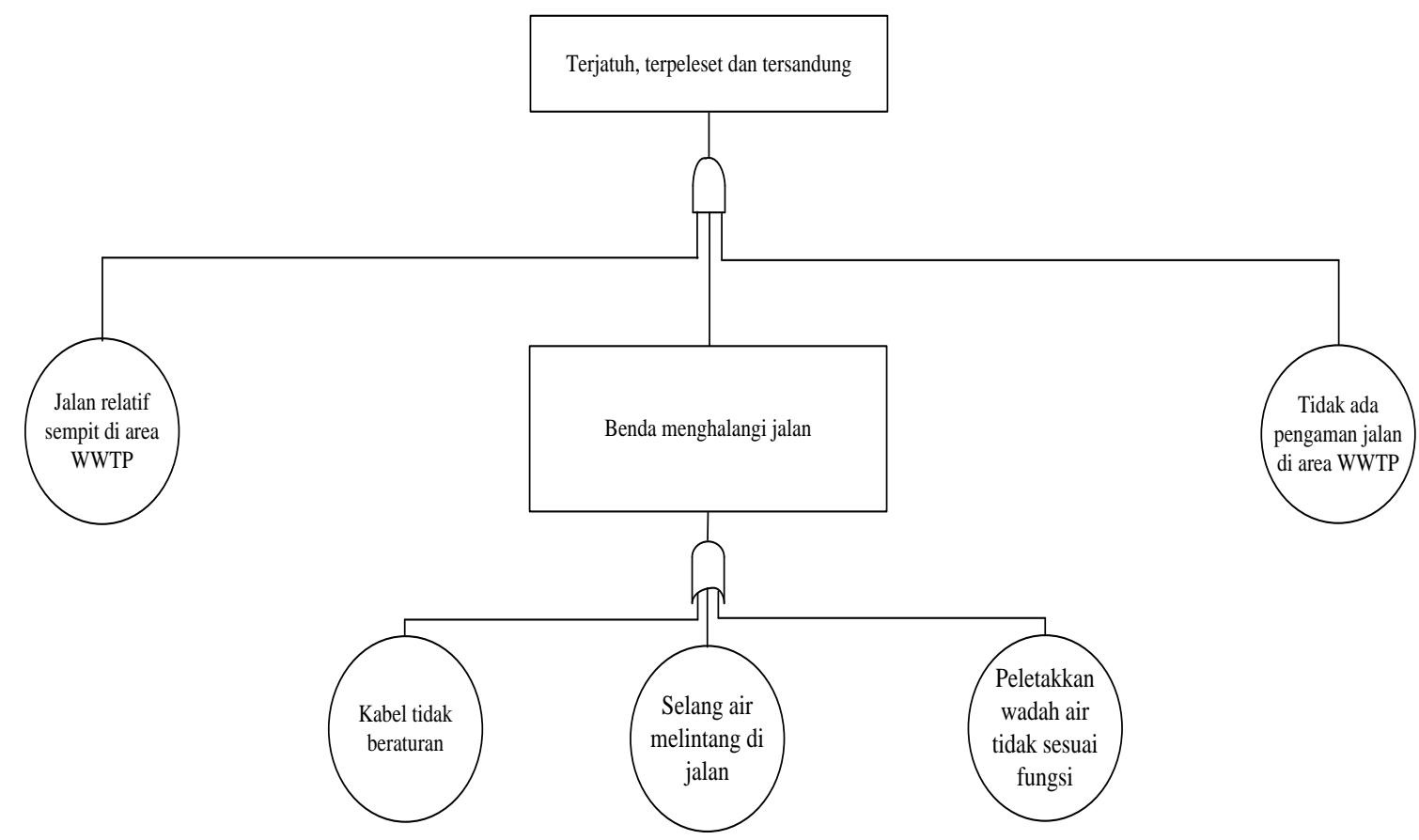

Gambar 5. Penyebab Potensi Bahaya Terjatuh, Terpeleset dan Tersandung

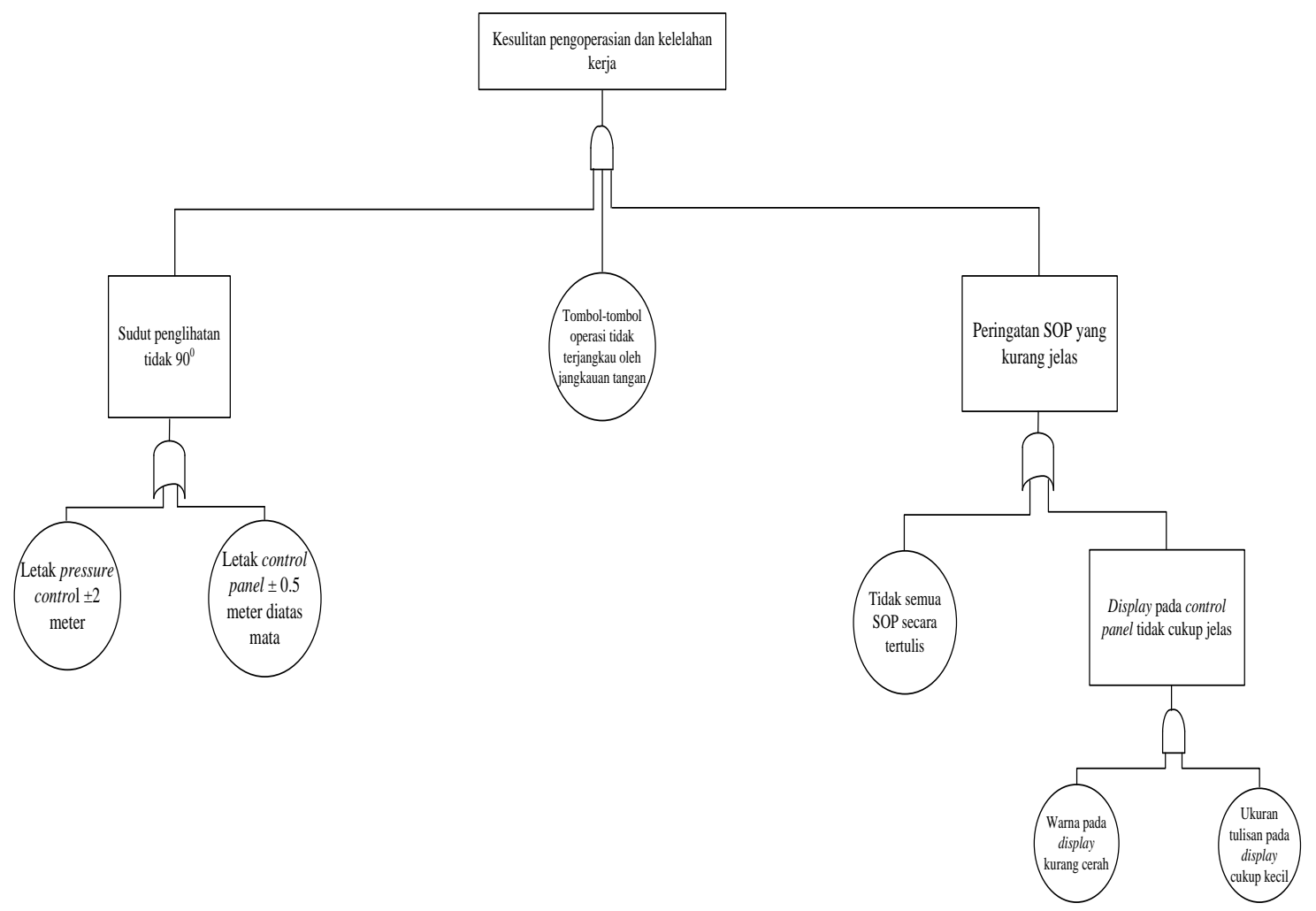

Gambar 6. Penyebab Potensi Bahaya Kesulitan Pengoperasian dan Kelelahan 


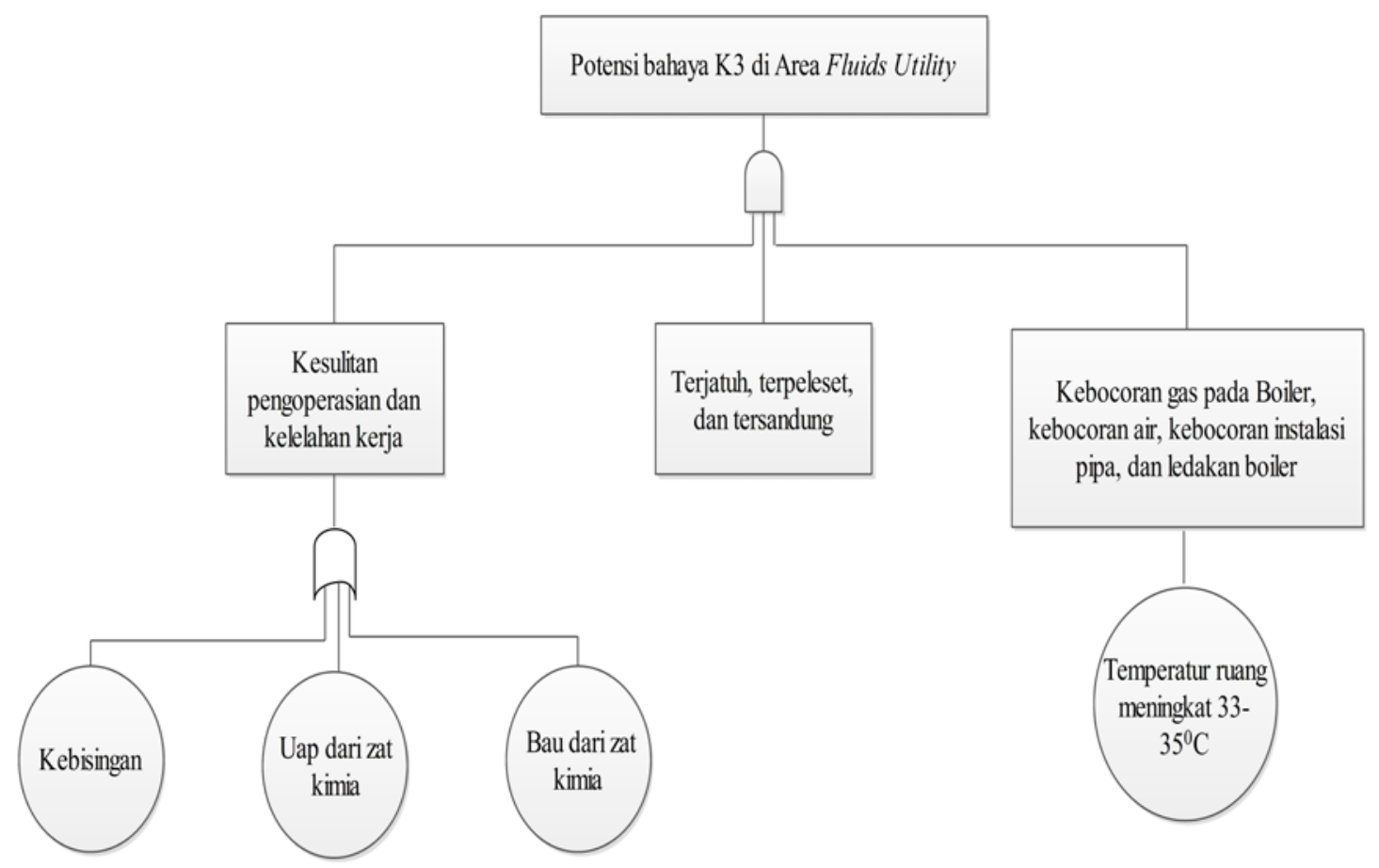

Gambar 7. Penyebab Potensi Bahaya Manajemen Keselamatan dan Kesehatan Kerja

\section{Penerapan Sistem Manajemen Keselamatan dan Kesehatan Kerja (SMK3)}

Penerapan SMK3 berdasarkan prinsip standar OHSAS 18001:2008 yang terdiri dari lima prinsip. Berikut (gambar 8) adalah lima prinsip penerapan SMK3 di PT Latinusa,Tbk berdasarkan OHSAS 18001:2008.

a. Kebijakan K3

Manajemen perusahaan memiliki komitmen untuk patuh terhadap peraturan perundangan K3, mencegah kecelakaan kerja, penyakit akibat kerja, dan pencemaran. Wewenang yang dimiliki manajemen puncak adalah memberi sanksi kepada karyawan yang bekerja dan investor di area pabrik tidak menggunakan alat keselamatan kerja.

b. Perencanaan

Perencanaan yang dilakukan perusahaan adalah membuat jadwal rencana kegiatan yang terdiri dari beberapa kegiatan yang dilakukan oleh divisi yang terkait untuk menerapkan SMK3 di perusahaan. Perusahaan melakukan identifikasi bahaya, penilaian resiko, dan pengendalian resiko K3 serta menanggulangi limbah terhadap pengendalian dampak lingkungan.

c. Pelaksanaan

Struktur dan tanggung jawab pelaksanaan SMK3 di perusahan dengan dibentuknya tim P2K3 (Panitia Pembina Keselamatan dan Kesehatan Kerja) yang merupakan bagian dari divisi keselamatan lingkungan dan damkar. Tim P2K3 adalah tim yang memiliki kewenangan, tanggung jawab, menyediakan sumberdaya manusia, sarana dan prasarana yang berkaitan tentang pelaksanaan SMK3 dengan manajemen perusahaan. Program-program yang dilakukan perusahaan sebagai pelaksanaan SMK3 dan keselamatan lingkungan diantaranya program kesehatan, program 
keselamatan, dan program lingkungan. Program keselamatan yang dilakukan diantaranya memasang rambu-rambu penggunaan alat pelindung diri di setiap area kerja, rambu-rambu peringatan akan bahaya kerja yang akan terjadi, menerapkan toolbox meeting, memberikan dan menyediakan alat pelindung diri bagi tenaga kerja secara gratis, sosialisasi dan rapat panitia pembina keselamatan dan kesehatan kerja (P2K3), mengadakan pelatihan K3 tentang P3K dan pelatihan tanggap darurat, melakukan patroli control setiap pagi selama jam kerja, dan penyedian alat pemadam kebakaran disetiap area kerja serta pemberian jalur evakuasi atau jalur hijau. Program peduli lingkungan yang diterapkan meliputi pengolahan limbah cair dan penggunaan kembali hasil limbah cair, penyediaan tempat sampah dan area penghijauan.

d. Pemeriksaan dan tindakan perbaikan

Pemeriksaan SMK3 yang dilakukan adalah dengan memantau dan mengukur faktor lingkungan kerja termasuk peralatan yang digunakan dan dampak terhadap lingkungan. Pemantauan dan pengukuran meliputi pencatatan informasi dan kejadian yang terjadi di lapangan secara kualitatif dan kuantitatif, melaksanakan audit K3 secara periodik. Tindakan perbaikan yang dilakukan meliputi patroli kontrol, mengevaluasi peraturan SMK3 yang diterapkan, melaporkan insiden yang terjadi dilapangan, mengidentifikasi pelaksanaan perbaikan seperti mendatangkan tim dari luar untuk pengujian emisi dan sertifikasi peralatan pabrik, melaporkan, perawatan alat keselamatan seperti alat pemadam kebakaran, dan mengevaluasi tentang penggunaan alat pelindung diri.

e. Kaji ulang manajemen

Pengkajian ulang manajemen yang diterapkan dilakukan untuk menjamin kesinambungan antara perencananan, pelaksanaan dan perbaikan berjalan sesuai yang di harapkan. Pengkajian ulang manajemen dilakukan dengan menyelengarakan rapat dan tinjauan antara tim P2K3 dengan manajemen puncak seperti direksi dan kepala divisi lainnya.

Lima prinsip penerapan SMK3 yang telah diterapkan untuk terus dilakukan perbaikan berkelanjutan oleh manajemen perusahaan. Perbaikan berkelanjutan dilakukan agar kesinambungan penerapan SMK3 dapat ditingkatkan sehingga mengurangi angka kecelakan kerja atau mendapatkan zero accident. SMK3 yang diterapkan diberlakukan untuk semua karyawan secara terntegrasi antara mesin, manuasia, material dan lingkungan, sehingga menghasilkan penghargaan zero accident atau nol kecelakaan pada tanggal 21 Oktober 2001 s.d 31 Oktober 2011 dan Oktober 2007 s.d 31 Oktober 2012, serta pada bulan April 2013 mendapatkan bendera emas atas penghargaan penerapan SMK3. Sertifikat yang diperoleh diantaranya sertifikat ISO 9001:2008, ISO 14001:2004, OHSAS 18001 dan sertifikat SMK3.

Potensi bahaya kerja yang teridentifikasi yaitu dengan kategori dominan low risk atau L menunjukkan bahwa program SMK3 dilingkungan kerja yang sudah memliki SMK3 dan penghargaan zero accident lebih ditingkatkan dalam penerapannya agar dapat diminimalisir dan mengantisipasi potensi bahaya yang akan terjadi. Pengawasan lebih ketat terhadap penerapan SMK3 yaitu dengan menerapkan juga reward terhadap karyawan yang patuh dan punishment terhadap karyawan yang melanggar, sehingga karyawan peduli akan keselamatan dan kesehatan kerja. Peraturan yang lebih ketat terhadap karyawan yang melanggar aturan dari penerapan SMK3 seperti penggunaan APD dan bertindak serta bekerja dengan peduli keselamatan dan kesehatan bukan karena unsafe behaviour. Penelitian Nurul,S (2012) yang tentang penerpan sistem manajemen K3 pada material handling di PT Multi Fabrindo Gemilang Cilegon-Banten hasil yang diperoleh menunjukkan bahwa penerapan SMK3 sudah sesuai standar Permenaker No. 
05/Men/96 dengan tidak adanya kecelakan kerja (zero accident) pada tahun 2006-2011 dan identifikasi potensi bahaya kerja yaitu dengan kategori dominan moderate risk atau M. Kondisi ini menunjukkan bahwa di suatu perusahaan yang memperoleh zero accident belum menjamin hasil identifikasi potensi bahaya kerja dengan kategori L, M, H, E atau bahkan tidak ada potensi bahaya.

\section{KESIMPULAN DAN SARAN}

\section{A. Kesimpulan}

Penelitian yang telah dilakukan dapat disimpulkan sebagai berikut :

a. Nilai resiko potensi bahaya kerja yang dominan di PT LT, bagian fluid utility adalah 2D yang berarti tingkat keparahan bahaya kerja kecil dan kemungkinan terjadinya potensi bahaya kerja kecil, sedangkan nilai kategori potensi bahaya kerja yang dominan adalah L yang berarti low risk atau resiko rendah sehingga perlu dikendalikan dengan prosedur rutin

b. Faktor penyebab terbesar terjadinya potensi bahaya kerja adalah kondisi ruangan relatif sempit dengan jumlah mesin yang tidak sebanding dengan ukuran ruangan, suara mesin bising, penggunaan bahan kimia berupa larutan elektrolit, penempatan Standard Operational procedure (SOP) pada empat mesin belum terpasang secara ergonomis, kondisi jalan sempit, terdapat benda asing yang menghalangi jalan, temperatur ruangan meningkat $5^{0} \mathrm{C}$ dari temperatur awal $28^{\circ} \mathrm{C}$

c. Pencapaian sistem manajemen keselamatan dan kesehatan kerja yang telah diterapkan sudah sesuai dengan undang-undang No.5 tahun 1970 ditunjukkan dengan perolehan penghargaan zero accident.

\section{B. Saran}

Adapun saran yang diajukan peneliti adalah sebagai berikut:

a. Pada penelitian selanjutnya, dalam mengidentifikasi potensi bahaya kerja dilakukan dengan beberapa metode identifikasi seperti JSA, Robinson, FMEA.

b. Mengidentifikasi potensi bahaya kerja dilakukan dalam beberapa area kerja yang sering dijangkau operator atau para pekerja.

\section{DAFTAR PUSTAKA}

[1] PT Latinusa, Tbk, 2011, Annual Report, Cilegon : PT Latinusa, Tbk.

[2] BATAN. 2004. Analisis Keselamatan Probabilistik. Jakarta: Pusdiklat.

[3] Dauly, Fristiyan Ahmad, 2010, Identifikasi Bahaya dan Upaya Pengendalian yang Dilakukan pada Pekerja Railing di PT PP (Persero) Proyek Fakultas Kedokteran dan Ilmu Kesehatan Universitas Islam Negeri Jakarta, Jakarta: Universitas Islam Negeri Jakarta.

[4] Dyahrini, Wien dan Alfiah Hasanah, 2010, Analisa Penerapan Sistem Manajemen Keselamatan dan Kesehatan Kerja (SMK3) Pada Proyek Pembangunan Rumah Toko (RUKO) Cirebon di PT Koprima Shandy Sejahtera Kontraktor (KSS). Jakarta: Universitas Widyatama.

[5] Putranto, Novi Marhaendra, 2009, Identifikasi Bahaya Bekerja Pada Daerah Bertegangan (Switchyard $150 \mathrm{kV}$ ) dengan Pendekatan Job Safety Anlysis (JSA) dan Hazard Identification Risk Assesment and Risk Control (HIRARC), Surabaya: Institut Teknologi Sepuluh November.

[6] Riyanto, 2012. Analisis Kerusakan Pada Hold Down Roll di PT Latinusa,Tbk, Jakarta: Universitas Pancasila.

[7] Rochmoeljati, Rr, 2009, Analisis Implementasi Program Keselmatan dan Kesehatan Kerja (K3) dan Perangkingan Hazard Dengan Pendekatan Manajemen Risiko, Jawa Timur: Universitas Pembangunan Nasional "Veteran”. 
[8] Saskia, Vinanti Nurul, 2012, Penerapan Sistem Manajemen K3 Pada Material Handling di PT Multi Fabrindo Gemilang Cilegon-Banten, Cilegon: Universitas Sultan Ageng Tirtayasa.

[9] Sulistyoko, Edhi, 2008, Analisis Penerapan Program Keselmatan Kerja Dalam Usaha Meningkatkan Produktivitas Kerja Dengan PEndektan Fault Tree Anlysis Studi kasus: CV.Permata 7, Wonogiri, Surakarta: Universitas Muhammadiyah Surakarta.

[10] Sutanto, Hadi, 2010, Analisis Faktor-faktor penyebab Kecelakaan Kerja Pada Pembangunan Gedung Perkantoran dan Perkuliahan Tahap III Universitas Wijaya Kusuma Surabaya, Surabaya: Institut Teknologi Sepuluh November.

[11] Susihono, Wahyu, 2012, Manajemen Bahaya Kerja I. Diktat Mata Kuliah Keselamatan dan Kesehatan Kerja. Cilegon; FT UNTIRTA.

[12] Tayanus, Novel dan Sri Yulia, 2005. Laporan Magang di PT Latinusa, Tbk,Padang: Akademi Hiperkes dan Keselamatan Kerja.

[13] Wijayanti, Nia Tri, 2008, Pengaruh Penerapan Safety Management Terhadap Kinerja Produktivitas Tenaga Kerja, Jakarta: Universitas Indonesia. 